\title{
A study on the factors affect to technological adoption of e-Government Information System interoperability in Vietnam
}

\author{
Nguyen Van Thanh \\ Ph.D Candidate in International IT Policy Program, College of Engineering, Seoul National University, Seoul, South \\ Korea \\ Email: nguyen@snu.ac.kr \\ Hyenyoung Yoon \\ Professor of International IT Policy Program, College of Engineering, Seoul National University, Seoul, South Korea
}

Junseok Hwang

Professor of International IT Policy Program, College of Engineering, Seoul National University, Seoul, South Korea

\begin{abstract}
Information system interoperability has an important role for e- Government development, specially in term of Public management information system. Each country has its own strategy in ensuring interoperability in information system. Nowadays, archiving interoperability among information system is very complex task. In developing countries, the building information system ensuring interoperability in public organizations is limited and ineffective. Moreover, without deeply understanding and determinance on interoperability dimensions, it will become a challenge for interoperability and E- Government implementation. Therefore, this study aims to investigate and analyze the interoperability factors which affect the adoption of Vietnam e-Government Information Systems interoperability. Moreover, data was gathered using survey through distributing questionnaires to the employees of IT departments in Vietnam public organizations. The data was analyzed through the technique of Structural equation modeling (SEM). The result shows that Risk Management, Collaboration and Coordination, Technical Expertise have significantly influence on Interoperability adoption in Government Information System in Vietnam.
\end{abstract}

Keywords: Information system, Public management information system, Interoperability, e- Government, Vietnam

\section{Introduction}

Nowadays, the purpose of Industry 4.0 to touch a high level of operational efficiency, productivity, and automatization throughout promoting emerging technologies, especially interoperability and integration 1 .

In case of E-Government, the transferring of technology knowledge in the organizations and can increase the competency can be helped by more accurate of technology to adopt innovative E-Government in developing countries ${ }^{2}$.
In E-Government ecosystem, Public Management Information System promotes strategic goals based on effectiveness, efficiency, and economy, includes social objectives, political and like as trust in governments, social inclusions, community well-being, community regeneration, and sustainability $\underline{3}$.

\subsection{E-Government ecosystems}

There are several E-Government ecosystems to use.

First, it is Public Management Information System. Regarding on Bozeman and Bretschneider, 1986, it is defined as Information system used in public 
management by public organizations. This ecosystem is important in public administration and public management sector $\stackrel{5}{ }$.

Second is E-Government Information System. Based on definition of Chen, S. C., Li, S. H., Li, C. Y., it is the systems to change the operations of government in public administration scope, setting up the relationships with citizen in country and make collaboration with different organizations. $\stackrel{21}{2}$

Third is Open government information system. Open Government is the decisive system for connecting and sharing information between the various components of the system: from national leadership, research and development institutions, and the law and policy system; to the cohesion of the resident community. -6 This system is the next generation of current ecosystems.

\subsection{Interoperability issues}

In the center position of E- Government ecosystem, Interoperability is defined like a set of multidimension, complementariment, and dynamic capability which are specified to defined networks of organization so that to achieve successful Interoperability $\underline{28}, \underline{29}$.

Moreover, the lacking of Interoperability has been a main challenger to E-Government maturity $\underline{7}, \underline{8}, \underline{9}$.

In Vietnam, the Government is taking important steps towards e-Government. There are many work being done in the legal field to support the operation of e-commerces. One of them is the E-Transaction Law, the basis for all electronic transactions in the private and public sectors. An Information Technology (IT) law is also being drafted by the Ministry of Posts and Telematics to serve the development of Information Technology Industry and Information Technology Management for Agencies, including the functions of the Chief Information Officer (CIO). $\underline{33}$

However, we face to challenges with data lost and fulladequate system. So we need to have Risk Management to solve this issue. We also have strong support and determinant from Vietnam government, so the Collaboration and Coordination is important in Interoperability adoption. Moreover, we have essential demand about high quality human resources, so we need to have many Technical expertise, especially in IT Interoperability. $\underline{30}, \underline{31}, \underline{32}$

Relate to research problem in this study, below is the literature overview about each research issue in the detail.
About interoperability dimensions, previous literature have lacking of concentrate view, only focus on four technical factors: IT security, ICT infrastructure, IT standards and technical expertise affect the current adoption of E-Government inventiveness in seven government organizations in Oman ${ }^{4,17}$.

About interoperability perceived, existing literature only focus on Perceived factors on electronic Government services, disconnect to the information sharing and interconnection in E-Government $\underline{10}, \underline{11}$.

About interoperability intention to use, previous literature are too emphasis on Intention to use and adopt e-service provision, E-Government overview, miss concern to the method how to connect and link among different elements in E-Government ecosystem $12,13,14$.

Next step we will show the research objective, research questions and hypotheses as well.

\section{$\square$ Research objective}

- This work aims to examine and analyze the interoperability factors which affect the adoption of Vietnam e-Government Information Systems interoperability.

\section{$\square$ Research questions}

What are the interoperability factors affect to interoperability adoption in E-Government Information Systems Interoperability?

\section{Literature Review}

\subsection{Interoperability}

Interoperability among Governments associations has been recognized as a focal issue and a basic essential for the viable working of contemporary associations frameworks $\underline{15}, \underline{16}, \underline{17}, \underline{18}$. To accomplish the interoperability governments, the joining of government data assets and procedures, and along these lines the interoperation of free data frameworks, are fundamental.

Economy advantages of interoperability result in lower exchange costs normally using institutionalized procedures. However, most coordination and interoperation endeavors confront genuine difficulties as well as limitation. Trades of data and administrations service are divided and complex, tormented by technological and organization issues $\underline{19}, \underline{20}$.

Interoperation in e-Government happens at whatever point free or heterogeneous data frameworks or their segments controlled by various purviews, organizations, or outside accomplices cooperate (proficiently and 
viably) in a predefined pattern. With e-Government interoperation, E-Government interoperability is one kind of technical ability $22,23,24$.

This study purpose is identify the main factors affect to the adoption of Interoperability in E- Government Information Systems in case of Vietnam.

The most common models within the field of Interoperability adoption and data systems success, and like the technology acceptance model and data system success models focus on the technology factor of the successful implementations of data system.

\subsection{Theories in applying}

The theoretical grounding for this model primarily comes from Technological- OrganizationalEnvironmental theory (TOE), and technology acceptance model (TAM). This model focuses on organizational factors (Collaboration and Coordination, Risk Management) and Technical factor (Technical Expertise). Moreover, this model focuses on the Perceived factors (Perceived Easy of Use, Perceived Usefulness and Perceived Trust). This study developed integrated model for prosperous adoption of EGovernment information systems Interoperability that link three factors (Interoperability dimensions, Perceived factors, and Intention to adopt Interoperability).

Organization interoperability: how organization collaborate to archive their objectives. Organization interoperability is archived through integration of exchanged information and various business processes $\underline{26}$.

Technical interoperability: concern both of Software and Hardware issues, focus on technical aspects, such as connecting or linking Information systems 27 .

E- Government need to exchange data and information with other systems. So it need to have Interoperability. However, we don't know about what elements we need to achieve Interoperability when implementing E- Government. So this study will solve this challenge.

Tripathi, R. P., Gupta, M. P., \& Bhattacharya, J. proposed a new framework which identify a group of interoperability to achieve adoption of interoperability based on three dimensions of integration. 11 They are communication integration, process integration, , and data integration. This framework focus on the factors in context of the portal of government departments in case of India. Moreover, these factors narrowed into organization factors which have strong relationship and interconnect with each other based on cause loop diagram display. $\frac{34}{3}$

In the other side, Sulehat, N. A., \& Taib, C. A. investigate the factors impact to E- Government Information Systems Interoperability in Jordan case study. $\underline{12}, \underline{13}$ This paper also show key successful factors as well as the barrier and challenger factors affect to implementation of E- Government development. By comparing and make matching with E- Government development strategy of Jordan, the paper also summary the research results from various sources of literature review. Then the results of paper show three main stages of interoperability to achieve successful implementation of E- Government Information Systems. 35 , 36 The main stages are also three layers of Interoperability aspect which discovered by European Interoperability Framework: technical, semantic and organization. To achieve e-transformation in case of Jordan, the study also suggests the working process and strategy should be aligned, and the standards and the knowledge should be shared with all citizens as well as public sector in developing country.

By another approach, Othman, M. H. B., \& Razali, R. through scan and review as well as using content analysis some key e- Government Interoperability Frameworks in different countries and different contexts. $\underline{15}, \underline{16}$ By that way, this paper identify the main factors which ensure successfulness for e- Government Information systems interoperability. These factors were grouped and divided into two different groups: people and process. Based on these key successful factors, the study propose the holistic framework for E-Government systems interoperability.

In the scope of technical side, Al-Rahbi, Y., AlHarrasi, S., \& Al-Wahaibi, S. described some technical factors which affect to the adoption of e- Government in term of e- Government project development, to enhance the e- Government services. These technical factors are also the technical interoperability factors. Focus on eGovernment cases in Oman country combine with investigate in six government organizations, this paper found the results that four main technical factors are: IT Infrastructure, IT security, IT standards and technical expertise. Moreover, these factors can be affected in term of management by external pressures like: government 
regulations, internet facilities, private sector attraction and citizen's awareness. $\underline{4}, \underline{17}$

By using Technology Acceptance Model (TAM), Colesca, S. E., \& Dobrica, L. provides the factors affect to adoption and implementation of e- Government Interoperability services in case of Romania.,-9 Most of the factors are demographic factors like: Age, Gender, Income, Education level, and IT infrastructure.

\subsection{Technology acceptance model}

The most popular technology acceptance model which is reviewed by previous researchers is TAM. In general, Technology Acceptance Model is one among the most common analysis models to predict intention to use and acceptance of knowledge systems and technology by individual users. $\frac{37}{}$ Moreover, Technology Acceptance Model is one amongst the foremost potent models wide utilized in the studies of the determinant of Information System and Technology acceptance. $\frac{38}{2}$

Davis, F.D., Bagozzi, R. P. Warshaw, P. R. developed the Technology Acceptance Model. Within the Technology Acceptance Model, there are two factors together with perceived ease of use and perceived usefulness. $\stackrel{20}{ }$ The below Figure depicts the Technology Acceptance Model.

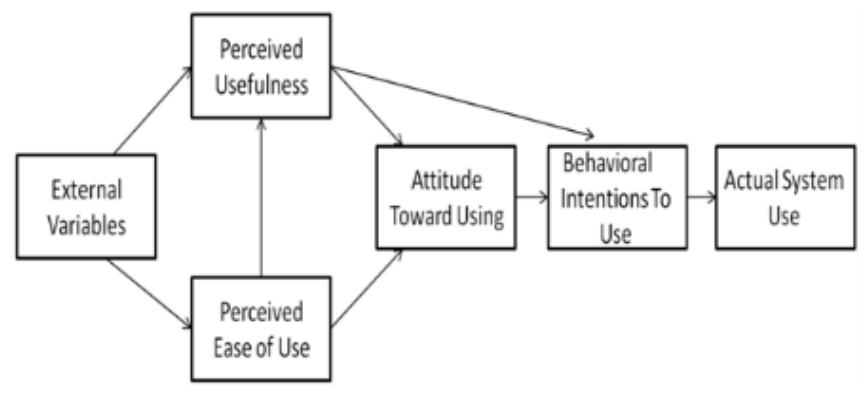

Figure 1. Technology Acceptance Model (Davis et al., 1989)

Perceived usefulness was outlined by Davis as "the degree to that a person believes that employing a explicit system would enhance his or her job performance". Individuals tend to use or to not use the applications to the extents they believe which it'll facilitate them to perform their job higher. Perceived usefulness explained the user's perception to the extent which the technology can improve the user's work performance.
Besides that, perceived easy use describes the user's perception of the quantity of effort needed to utilize the system or the extent to that a user believes that employing a explicit technology are easy. $\underline{20}$

Based on several scholars, easy of use may be a live of the system quality. Hence, a number of researcher include easy use as a live of the system quality. $\underline{39}, \underline{40}, \underline{41}, \underline{42}$

In conclusion, Technology Acceptance Model (TAM) suggested that once a replacement technology is conferred to the users, the users decide once and the way they're going to use the technology supported variety of factors: perceived usefulness and perceived ease-of-use. Look that use or acceptance of the technology in some cases desires another issue such as: Risk management, Collaboration and coordination, Technical expertise ...

Moreover, previous analysis had used system usages and user satisfactions to live system success as well as also the TAM variables to predict usage of information systems interoperability. $\frac{43}{-}$ However, researchers afterward instructed that TAM variable may be scant predictors of system interoperability usage and success. What's necessary is that they used user performance or what's generally referred to as individual impacts as indicators to system success or system effectiveness. Risk management might enhance the employee's intention to use or adopt the interoperability once they see it's helpful. .4 Consistent with another research for IS interoperability acceptance, collaboration and coordination ought to specialize in providing comfortable support. Moreover, collaboration and coordination offers important impacts on the data systems interoperability performances. $\underline{45}$ In addition, Technical expertise is that the most essential factor associated with Information system interoperability usage. $\underline{46}$ Hence, there are many aspects to encourage the end-user to simply accept or use the Interoperability.

In e-Government ecosystems, all of them consider eGovernment like the most important technology to make effectiveness and successfulness of ecosystem development. With the role of core component in ecosystems, e-Government is adapt well to fit with Technology Acceptance Model. This model investigates and examines the acceptance of emerging technologies like e-Government. Therefore, Technology Acceptance Model is totally suitable for E-Government ecosystems. 


\subsection{Technology, Organization, and Environment Framework}

In 1990, Technology, Organization and Environment (TOE) Framework was proposed. This framework identified three dimensions of an organization's context which effect to stream by which it adopted and implemented a technology innovation: Technological dimension, Organizational dimension and Environmental dimension. As originally presented, and later adapted in IT adoption studies, the Technology, Organization and Environment (TOE) provided a usefully analytic framework which could be used for learning the adoption and consideration of different kinds of Information Technology innovative. $\frac{47}{}$ The below figure describes the theory.

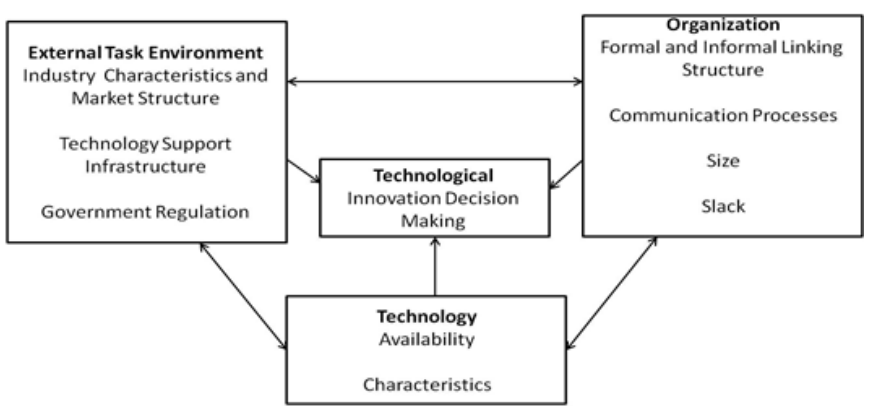

Figure 3: Technology, Organization, and Environment Framework (Tornatzky \& Fleischer, 1990)

Based on Tornatzky \& Fleischer, the technological perspective contains the external and internal technologies that are related to the organization. Technologies could include each instrumentation further as processes. The structure perspective mentions to the characteristics and resources of the organization as well as the organization size, degree of concentration, degree of righteousness, social control structure, human resources, quantity of loose capitals and connections amongst workers. The environmental perspective contains the scale and structure of the business, the organization competitors, the economic science perspective and the regulative atmosphere.

In instant, TOE framework is concentrated organization (informal and formal link structure, communication process, size and loose), technology (accessibility and features), , and atmosphere (industrial features and market structures, technology supporting infrastructures and government rule). However these factors aren't consistent with the opposite scholars. A theoretical framework for acceptance of education management system was established in Asian country. $\underline{48}$ This framework offers a complete have a look at the vital factors. These vital factors are associated with the trainer, organization and technology. Technology factors may be related to the system qualities, information qualities and service support qualities. Organization factors may be associated with motivation, technology arrangement, organization supports, technical supports and coaching. educator factors may be associated with self-efficacy, attitude toward systems, experience, teaching vogue and private originality. User characteristics may be associated with age, education, IS expertise, user involvement and participation and coaching. structure characteristics may be associated with high management support, structure culture and business method reengineering. Moreover, humans, organizations and technologies are the important elements of Information System; the impacts of human are assessed within-the web advantages. ${ }^{49}$ Technology factors may be related to the system qualities, info qualities and repair support qualities. Human factors may be associated with system uses and users satisfaction. Organization factors may be related to structure and atmosphere.

\subsection{Limitation of previous research}

Most studies focus only on systematic links in the field of public administration. Scholars focused on how to identify the major acting forces in Information system interoperability in Public Administration. $\underline{20}$

There have been few studies on the problem of integrating data in public management information systems.

There is separate research about Technical factors, organization factors, perceived factors. No concentrate study include all of these factors in E-Government Interoperability.

\section{Research Model}

\section{Research design:}

Questionnaire design

We assumed an concentrated research of literature of interest to character current measure for related construct. 
The questionnaires was pilot tested with fourteen industry experts. Then we showed face to face debates with those experts after they finished the questionnaires. We changed, additional and delete question to improve the survey based on their feedbacks.

Likert Scale is adopted in this research as it is the most usually adopted measures in scale design, with the 3-point and 5-point Likert scales generally liking the largest popularities. Nevertheless, Berdie addressed this questionnaires design in his work and protects the 6-point Likert scale for the following three reasons. Firstly, in most use cases, a 6-point Likert Scale is the most consistent measure methodology. Once the question are over seven, it is hard for human to differentiate the right fact. Second, a 3-point Likert Scale reduces people's strongest and mildest view, while a 6-point Likert Scale can definite it preferably. Third, a 6-point Likert Scale reasons misunderstanding for those human with poor differentiate capability. Therefore, the research used the 6-point Likert Scale, with the responses rated as follows: 1 as strongly disagree, 2 as disagree, 3 as slightly disagree, 4 as slightly agree, 5 as agree, and 6 as strongly agree.

Survey questionnaires (sent to 397 people, 205 received, response rate of 51.6 percent)

Figure 4: Research model

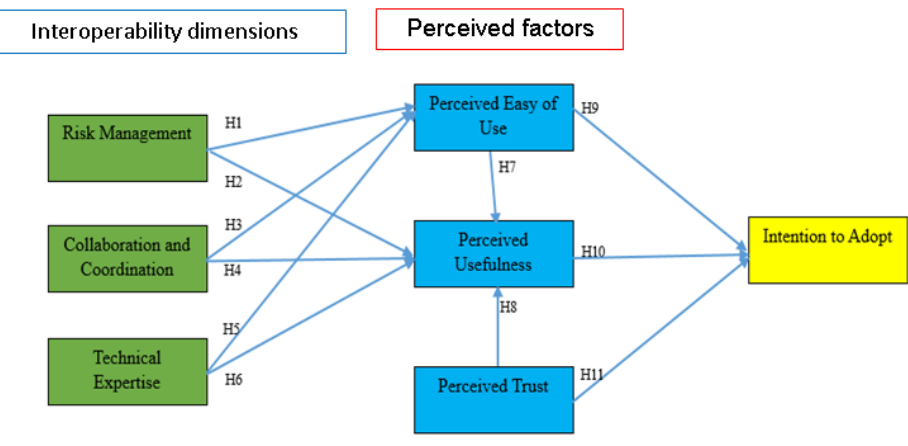

\section{Hypotheses development}

\section{Risk Management}

It is defined as formal continuous process to avoid the failure of E-Government Information Systems. $\underline{50}$ Risk Management could impact to interoperability attitude to use and usefulness based on launch cost and operating cost. $1, \underline{12}$ Therefore, I hypothesize the factor as:

H1. Risk management has positively influence on Perceived Easy of Use.
H2. Risk management has positively influence on Perceived Usefulness.

\section{Collaboration and Coordination}

Among various and different organizations, they have shared vision and collaboration through coordination to achieve their purpose. .51 Collaboration and Coordination can effect to interoperability attitude to use and usefulness $\underline{11}, \underline{12}$.

Therefore, I hypothesize the factor as:

H3. Collaboration and Coordination has positively influence on Perceived Easy of Use.

H4. Collaboration and Coordination has positively influence on Perceived Usefulness.

\section{Technical expertise}

It is defined as skilled people with strong IT skills with experience in develop and implement E-Government Information Systems. Technical expertise can effect to interoperability attitude to use and usefulness of EGovernment. $\underline{52}$

Therefore, I hypothesize the factor as:

H5. Technical expertise has positively influence on Perceived Easy of Use.

H6. Technical expertise has positively influence on Perceived Usefulness.

\section{Perceived Easy of Use (PEOU)}

In TAM model, there are two factors together with perceived ease of use and perceived usefulness. $\underline{53}$

Besides that, perceived easy use describes the user's perception of the quantity of effort needed to utilize the system or the extent to that a user believes that employing a explicit technology are easy. $\underline{20}$

Therefore, I hypothesize the factor as:

H7. Perceived Easy of Use has positively influence on Perceived Usefulness.

H9. Perceived Easy of Use has positively influence on Intention to adopt.

Perceived Usefulness (PU)

Perceived usefulness is definite as the grade to which a person believes that using the new technology will improve his/her task performance. $\underline{52}$ Moreover, perceived usefulness is the grade to which an individual believes that using the system improves his or her job performance. Perceived usefulness is definite as the prospective user's subjective possibility which adopting a specific application system would rise his or her job performance within an organizational perspective. $\underline{20}$ In addition, the items to measure the perceived usefulness are productivity, make things easier, and overall useful. 
Moreover, the items to measure the perceived usefulness are the system enabled me to accomplish tasks more quickly, improved the quality of my tasks, and as a whole, useful to me. Hence, the items to measure the perceived usefulness are improves the quality, makes it easier to do my job and useful in my job. $\frac{18}{}$

In this research, three items were adopted to quantity perceived usefulness construct. Those items are adopting the system in my work allows me to achieve tasks more rapidly, using the systems make it easier to do my work, and general I found the system useful to my work. $\underline{\underline{20}}$

There are six items to measure perceived usefulness construct. Those items are: using the systems in my work allows me to achieve tasks more rapidly, adopting the systems improved my work performance, adopting the systems in my work rises my productivity, adopting the systems improve my effectiveness on the work, adopting the systems make it easier to do my work, and general, I found the systems useful to my work. Moreover, effectiveness, productivity and performance of the job are measures for individual performance impact. For that, in this study only three items were used to measure perceived usefulness construct. $\frac{20}{}$ The rest of the items (adopting the systems improve my work performance, adopting the systems in my work rises my productivity, adopting the systems enhanced my effectiveness on the work) will use to measure the individual performance impact as mentioned.

Perceived usefulness was described as "the degree to that a person believes that employing a explicit system would enhance his or her job performance". Individuals tend to use or to not use the applications to the extents they believe which it'll facilitate them to perform their job higher. Perceived usefulness explained the user's perception to the extent which the technology can improve the user's work performance.

Therefore, I hypothesize the factor as:

H10. Perceived Usefulness has positively influence on Intention to adopt.

\section{Perceived Trust}

It is defined as perceive of user about trustworthiness, privacy, security and risk of e-Government Information Systems Interoperability. Some scholars mentioned that Perceived Trust can has effect to Perceived Usefulness when users use new technology. In another way, Perceived Trust also has impact on Intention to use eGovernment interoperability. $\underline{21}, \underline{22}, \underline{23}$

Therefore, I hypothesize the factor as:
H8. Perceived Trust has positively influence on Perceived Usefulness.

H11. Perceived Trust has positively influence on Intention to adopt. ${ }^{54}$

\section{Research Methodology}

\begin{tabular}{|c|c|c|}
\hline \multicolumn{2}{|l|}{ Variable } & \multirow[b]{2}{*}{$\begin{aligned} & \text { measurements } \\
& \text { - } \text { Risk } \\
& \text { committee } \\
& \text { - } \text { Full adequate } \\
& \text { system } \\
& \text { - } \text { Frequency of } \\
& \text { backup } \\
& \text { - } \text { Quality of } \\
& \text { backup }\end{aligned}$} \\
\hline \multirow{3}{*}{$\begin{array}{l}\text { Interoperability } \\
\text { dimensions }\end{array}$} & $\begin{array}{l}\text { Risk } \\
\text { management }\end{array}$ & \\
\hline & $\begin{array}{l}\text { Collaboration } \\
\text { and } \\
\text { Coordination }\end{array}$ & $\begin{array}{lll}\text { - } & \text { IT } & \text { staff } \\
& \text { meeting } & \\
\text { - } & \text { Make } \\
& \text { agreement } \\
& \text { together } \\
\text { - } & \text { Shared IT } \\
& \text { project } \\
\text { - } & \begin{array}{l}\text { Knowledge } \\
\text { sharing }\end{array} \\
\end{array}$ \\
\hline & $\begin{array}{l}\text { Technical } \\
\text { expertise }\end{array}$ & $\begin{array}{ll}\text { - } & \text { Number of IT } \\
\text { experts } \\
\text { - } \\
\text { Quality of IT } \\
\text { experts }\end{array}$ \\
\hline \multirow{3}{*}{$\begin{array}{l}\text { Perceived } \\
\text { factors }\end{array}$} & $\begin{array}{l}\text { Perceived } \\
\text { Easy of Use }\end{array}$ & $\begin{array}{ll}\cdot & \text { Usability } \\
\cdot & \text { Navigation } \\
\cdot & \text { Accessibility } \\
\text { - } & \text { Helpfulness } \\
\end{array}$ \\
\hline & $\begin{array}{l}\text { Perceived } \\
\text { Usefulness }\end{array}$ & $\begin{array}{ll}\text { - } & \text { Content } \\
\text { - } & \text { Timeliness } \\
\text { - } & \text { Transparency } \\
\text { - } & \text { Pricing } \\
\text { - } & \text { Accountability } \\
\end{array}$ \\
\hline & $\begin{array}{l}\text { Perceived } \\
\text { Trust }\end{array}$ & $\begin{array}{ll}\text { - } & \text { Trustworthines } \\
& \mathrm{s} \\
\text { - } & \text { Privacy } \\
\text { - } & \text { Security } \\
\text { - } & \text { Risk }\end{array}$ \\
\hline
\end{tabular}


Nguyen Van Thanh, Hyenyoung Yoon, Junseok Hwang

\begin{tabular}{|l|l|ll}
\hline & & & $\begin{array}{l}\text { Willingness to } \\
\text { Intention }\end{array}$ \\
Intention to & & $\begin{array}{l}\text { use } \\
\text { adopt }\end{array}$ & $\begin{array}{l}\text { Intention to use } \\
\text { Frequency of } \\
\text { use }\end{array}$ \\
\hline
\end{tabular}

Table 1. Variable specification

Risk committee: It is visible committee for ensure risk management in organizations. It is one of measurements of Risk management which stands for Organizational Interoperability dimension in e-Government ecosystems. Full adequate system: It is the system with full functions to register, monitor and report risks for E-government ecosystem. It is one of measurements of Risk management which stands for Organizational Interoperability dimension in e-Government ecosystems.

Frequency of backup: It is the frequency of organizations to perform backup for E-government information system in a regular. It is one of measurements of Risk management which stands for Organizational Interoperability dimension in eGovernment ecosystems.

Quality of backup: It is the quality of E-government sites backup to ready for disaster recovery. It is one of measurements of Risk management which stands for Organizational Interoperability dimension in eGovernment ecosystems.

IT staff meeting: It is the level of regular meetings with IT staff from different public organizations. It is one of measurements of Collaboration and Coordination which stands for Organizational Interoperability dimension in eGovernment ecosystems.

Make agreement together: It is the level of organization's participation in formulating the agreements related to information systems with IT staff from other public organizations. It is one of measurements of Collaboration and Coordination which stands for Organizational Interoperability dimension in eGovernment ecosystems.
Shared IT project: It is the level of organization's participation in working with IT staff from other public organizations for shared IT projects. It is one of measurements of Collaboration and Coordination which stands for Organizational Interoperability dimension in eGovernment ecosystems.

Knowledge sharing: It is the level of organization to share IT knowledge with IT staff from other public organizations. It is one of measurements of Collaboration and Coordination which stands for Organizational Interoperability dimension in e-Government ecosystems.

Number of IT experts: It is the number of technical experts in each organization who deal with Egovernment information system. It is one of measurements of Technical expertise which stands for Technological Interoperability dimension in eGovernment ecosystems.

Quality of IT experts: It is the experience level of technical experts in each organization who deal with Egovernment information system. It is one of measurements of Technical expertise which stands for Technological Interoperability dimension in eGovernment ecosystems.

Usability: It is the perceive level about easiness of use of an e-government service. It is one of measurements of Perceived Easy of Use which is one of the key Perceived factors in e-Government ecosystems.

Navigation: It is the easy level of navigation capability around an e-Government website. It is one of measurements of Perceived Easy of Use which is one of the key Perceived factors in e-Government ecosystems.

Accessibility: It is the capability of e-Government services to provide access for everyone. It is one of measurements of Perceived Easy of Use which is one of the key Perceived factors in e-Government ecosystems.

Helpfulness: It is the benefit of e-Government systems to provide expected assistance to the users. It is one of measurements of Perceived Easy of Use which is one of the key Perceived factors in e-Government ecosystems. 
Content: It is the precise information which eGovernment systems provide to the user. It is one of measurements of Perceived Usefulness which is one of the key Perceived factors in e-Government ecosystems.

Timeliness: It is the up-to-date information which eGovernment systems provide to the user. It is one of measurements of Perceived Usefulness which is one of the key Perceived factors in e-Government ecosystems.

Transparency: It is the benefit of e-Government systems to actively give the user's opinion to the government. It is one of measurements of Perceived Usefulness which is one of the key Perceived factors in e-Government ecosystems.

Pricing: It is the time saving, money saving when using e-Government systems. It is one of measurements of Perceived Usefulness which is one of the key Perceived factors in e-Government ecosystems.

Accountability: It is the cability to communicate with government officials through e-Government systems. It is one of measurements of Perceived Usefulness which is one of the key Perceived factors in e-Government ecosystems.

Trustworthiness: It is the feeling of user that the eGovernment services providers are trustworthy. It is one of measurements of Perceived Trust which is one of the key Perceived factors in e-Government ecosystems.

Privacy: It is the feeling level of users about their privacy protection when using e-Government services. It is one of measurements of Perceived Trust which is one of the key Perceived factors in e-Government ecosystems.

Security: It is the secure level of users' data transfering when using e-Government services. It is one of measurements of Perceived Trust which is one of the key Perceived factors in e-Government ecosystems.

Risk: It is some negative consequences from using eGovernment services. It is one of measurements of Perceived Trust which is one of the key Perceived factors in e-Government ecosystems.
Willingness to use: It is the positive attitude of organizations toward using e-Government systems. It is one of measurements of Intention to adopt which stands for Intention factor in e-Government ecosystems.

Intention to use: It is the intention level to use eGovernment systems of organizations. It is one of measurements of Intention to adopt which stands for Intention factor in e-Government ecosystems.

Frequency of use: It is how often the organizations use e-Government systems. It is one of measurements of Intention to adopt which stands for Intention factor in eGovernment ecosystems.

For testing the hypotheses which are proposed in this study, the dataset was analyzed using Structural Equation Modeling (SEM).

We use SEM model to identify how determinant factors influence on intention to adopt Interoperability.

Research question: What are the interoperability factors affect to interoperability adoption in e-Government Information Systems?

The projected analysis model was analyzed exploitation the structural equation modeling (SEM) supported by Analysis of Moment Structures (AMOS) and also the SPSS (Statistical Package for the Social Sciences) software package program. AMOS may be a SEM package supported with SPSS. AMOS (Analysis of Moments Structures) is one in all the latest software package developed and offered within the market which allowed scholars to model and analyze the inter relationships amongst construct having multiple indicators efficiently, exactly and expeditiously.

From literature, scholars used the structural equation modeling technique rather than different techniques because some reasons: the previous techniques like multivariate analysis, correlational analysis, statistical procedure of variance and discriminant analysis can only examine one relationship at a time. It doesn't let to check the researcher's entire theory. For this reason, we used structural equation modeling (SEM). Structural equation modeling will inspect a series of dependence relationships at the same time.

Table 2, 3, 4 show the sample characteristics of the data Table 2. Responder's position - frequency 


\begin{tabular}{l|r|r|} 
& \multicolumn{2}{|c}{ Position } \\
\hline & Frequency & Percent \\
\hline Board of Director & 12 & 5.9 \\
Consult expert & 12 & 5.9 \\
Division manager & 65 & 32.2 \\
IT Supervisor & 1 & .5 \\
Lecturer & 13 & 6.4 \\
Manager of Department/ & 22 & 10.9 \\
Institute/ Agency/ Center & 12 & 5.9 \\
Officer & 7 & 3.5 \\
Others & 33 & 16.3 \\
Specialist & 25 & 12.4 \\
Team leader & 202 & 100.0 \\
Total & & \\
\hline
\end{tabular}

Table 3. Type of organization - frequency Organization kind

\begin{tabular}{l|r|r|}
\hline & Frequency & Percent \\
\hline Company & 14 & 6.9 \\
Department & 84 & 41.6 \\
Financial, Bank & 11 & 5.4 \\
Hospital & 4 & 2.0 \\
Institute & 15 & 7.4 \\
Academy & 1 & .5 \\
Ministry & 45 & 22.3 \\
Others & 12 & 5.9 \\
University & 16 & 7.9 \\
Total & 202 & 100.0 \\
\hline
\end{tabular}

202 observations were available for the study.

Cronbach's Alpha showed that all the variables were under acceptable limits with all scores above 0.7
Table 4. Gender

\begin{tabular}{l|r|r|}
\multicolumn{2}{c}{ Gender } \\
\hline & Frequency & Percent \\
\hline & 1 & .5 \\
Female & 58 & 28.7 \\
Male & 143 & 70.8 \\
Total & 202 & 100.0 \\
\hline
\end{tabular}

Table 5. Education level

Education level

\begin{tabular}{l|r|r|}
\hline & Frequency & Percent \\
\hline College & 7 & 3.5 \\
Doctor & 34 & 16.8 \\
Master & 80 & 39.6 \\
MBA & 1 & .5 \\
Trade school & 1 & .5 \\
University & 79 & 39.1 \\
Total & 202 & 100.0 \\
\hline
\end{tabular}




\begin{tabular}{lll} 
Item code & Alpha & Mean \\
\hline RM1 & & 3.51 \\
RM2 & 0.937 & 3.33 \\
RM & & \\
\hline COC1 & & 15.77 \\
COC2 & & 15.85 \\
COC3 & & 15.53 \\
COC4 & 0.835 & 15.40 \\
COC & & \\
\hline TE1 & & 16.36 \\
TE2 & & 16.34 \\
TE3 & & 16.27 \\
TE4 & 0.751 & 16.22 \\
TE & & \\
\hline PEU1 & 15.62 \\
PEU2 & & 15.65 \\
PEU3 & & 15.54 \\
PEU4 & & 15.50 \\
PEU & & \\
\hline PU1 & & 10.54 \\
PU2 & & 10.46 \\
PU3 & & 10.42 \\
PU & & \\
\hline PT1 & & 15.12 \\
PT2 & & 15.35 \\
PT3 & & 15.13 \\
PT4 & & 15.18 \\
PT & & \\
\hline ITA1 & & \\
ITA2 & & \\
ITA3 & & \\
ITA & & \\
\hline & & \\
& & \\
\hline
\end{tabular}


Nguyen Van Thanh, Hyenyoung Yoon, Junseok Hwang

Table 6: Descriptive statistics and Cronbach's alpha

Model validity measures: Discriminant validity was checked as evidenced by AVE where all values were above 0.5

\begin{tabular}{lll}
\hline & $\begin{array}{l}\text { AVE (Average Variance } \\
\text { Extracted) }\end{array}$ & CR (Composite Re \\
RM & 0.936 & \\
COC & 0.691 & 0.967 \\
TE & 0.580 & 0.899 \\
PEU & 0.573 & 0.843 \\
PU & 0.719 & 0.843 \\
PT & 0.538 & 0.885 \\
ITA & 0.683 & 0.820 \\
\hline
\end{tabular}

Table 7: AVE and CR

\begin{tabular}{|l|l|}
\hline Cronbach's Alpha & $\begin{array}{l}\text { Number of } \\
\text { constructs }\end{array}$ \\
\hline 0.734 & 5 \\
\hline
\end{tabular}

Table 8. Reliability Statistics

EFA: the pattern matrix of each individual factor with all values above 0.5 was obtained which showed the consistency of the data 


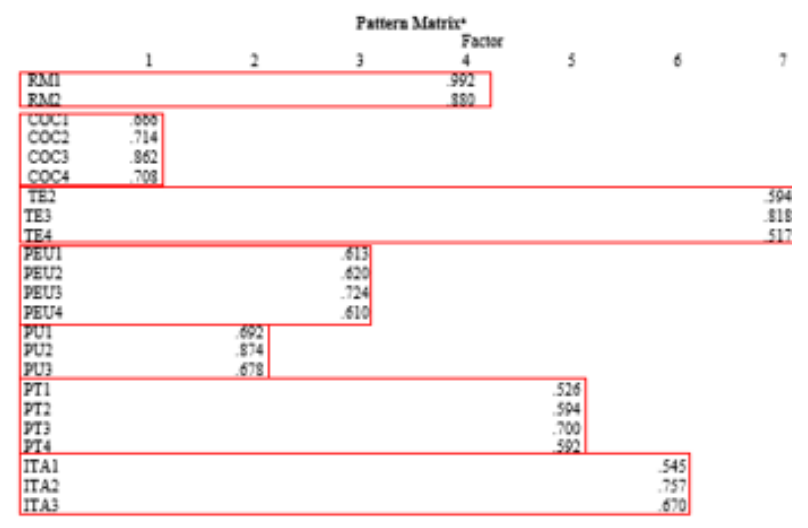

Table 9. Pattern Matrix

The model fit for the proposal was checked and the measures obtained which indicated that the model fulfilled the thresholds considered acceptable.

Table 10. Model fit measures - SEM

Table. Model fit measures - SEM

\begin{tabular}{lll}
\hline Measure & Estimate & Threshold \\
CMIN & 386.967 & \\
DF & 232 & \\
CMIN/DF & 1.668 & Between 1 and 3 \\
CFI & 0.924 & $>0.9$ \\
TLI & 0.909 & $>0.9$ \\
RMSEA & 0.046 & $<0.05$ good \\
SRMR & 0.05 & $<0.09$ \\
PCLOSE & 0.107 & $>0.05$ \\
\hline
\end{tabular}

We found that 6/11 hypotheses are accepted,

$5 / 11$ hypotheses are rejected.

Figure 5. Results of the path analysis

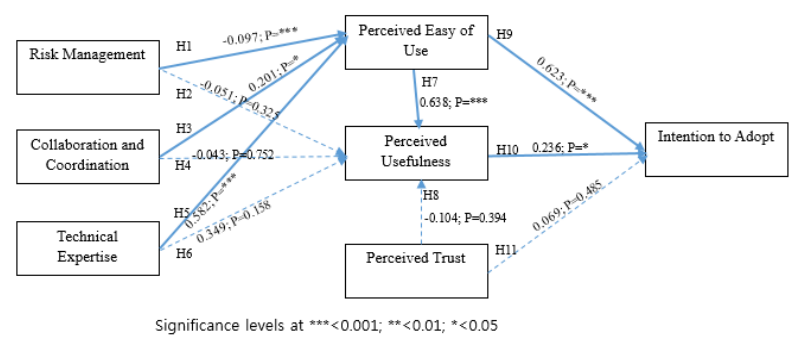


Table 11. Results of Hypothesis test

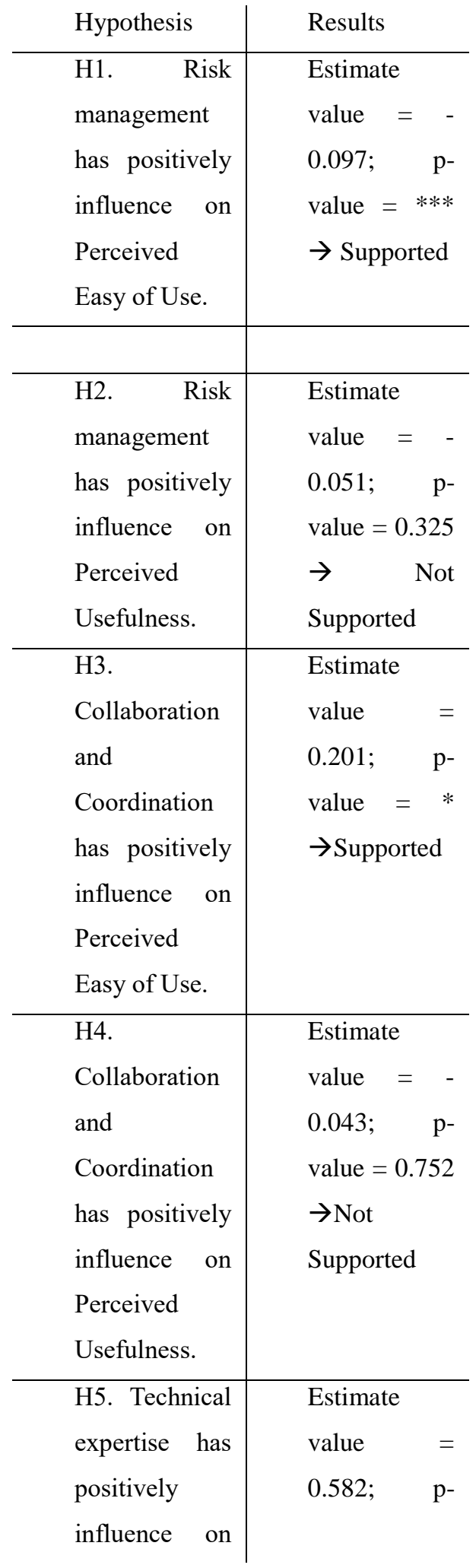

\begin{tabular}{|c|c|}
\hline $\begin{array}{l}\text { Perceived } \\
\text { Easy of Use. }\end{array}$ & $\begin{array}{l}\text { value }=* * * \\
\rightarrow \text { Supported }\end{array}$ \\
\hline H6. Technical & Estimate \\
\hline expertise has & value \\
\hline positively & $0.349 ; \quad$ p- \\
\hline influence on & value $=0.158$ \\
\hline Perceived & $\rightarrow$ Not \\
\hline Usefulness. & Supported \\
\hline H7. Perceived & Estimate \\
\hline Easy of Use & value $\quad=$ \\
\hline has positively & $0.638 ; \quad \mathrm{p}-$ \\
\hline influence on & value $=* * *$ \\
\hline Perceived & $\rightarrow$ Supported \\
\hline Usefulness. & \\
\hline H8. Perceived & Estimate \\
\hline Trust has & value $=-$ \\
\hline positively & $0.104 ; \quad \mathrm{p}-$ \\
\hline influence on & value $=0.394$ \\
\hline Perceived & $\rightarrow \mathrm{Not}$ \\
\hline Usefulness. & Supported \\
\hline H9. Perceived & Estimate \\
\hline Easy of Use & value $\quad=$ \\
\hline has positively & $0.623 ; \quad p-$ \\
\hline influence on & value $=* * *$ \\
\hline Intention to & $\rightarrow$ Supported \\
\hline adopt. & \\
\hline H10. & Estimate \\
\hline Perceived & value \\
\hline Usefulness has & 0.236 \\
\hline positively & value $=*$ \\
\hline influence on & $\rightarrow$ Supported \\
\hline Intention to & \\
\hline adopt. & \\
\hline H11. & Estimate \\
\hline Perceived & value \\
\hline Trust has & 0.069 \\
\hline
\end{tabular}




\begin{tabular}{lr|l} 
positively & & value $=0.485$ \\
influence & on & $\rightarrow$ Not \\
Intention & to & Supported \\
adopt. & &
\end{tabular}

\section{Discussion and Implications}

From the results, we can see this study addressed the research question that evaluate the relationship between interoperability dimension factors, and perceived factors. Moreover, analysis the relationship between interoperability dimension factors, and perceived factors and Intention to adopt. Moreover, evaluate the relationship between perceived usefulness and perceived easy of use with Intention to adopt. Data was collected using the survey questionnaires. The result 202 effective cases were evaluated with the SEM technique to validate the theoretical models and test the hypotheses, then address the research questions.

Organization factors and Technical factors such as: Risk management, Collaboration and Coordination, Technical Expertise did not show a significant influence on Perceived Usefulness. This can be explained as Interoperability in Vietnam is new with Organization, especially for Public Organization such as Government agencies. So they did not have chance to use Interoperability applications yet.

Perceived Easy of Use and Perceived Usefulness show significant influence on Intention to Adopt. This can be explained as the Public organization Information System consider characteristic of using and Usefulness more than Trust Perceive.

There is no significant influence from Perceived Trust on Intention to Adopt. The reason is Interoperability ability in Vietnam is not stable compared to developed countries. The inefficient information system infrastructure and poor investment are a handicap to government efforts related to E-Government launch. In Vietnam, Interoperability is not user-friendly. As a result, the majority of Vietnamese may prefer traditional government procedures rather than using e-Government services. Therefore, perceived usefulness does not have a strong impact on intentions to use. $\frac{54}{4}$

\section{Contributions and Limitations}

\subsection{Theoretical contribution}

The first contribution of this study is about theoretical. This research first attempts to investigate the determinant factors in E-Government interoperability adoption through combining information system success theory and T-O-E theory. Organization factors is new point in E-Government adoption model. We find that Organization and Technical factors only impact on Perceived Easy of Use.

\subsection{Practical contribution}

In practical contribution, this study's results help Government, policy makers and researchers consider the way and elements to implementing E-Government Information systems in Vietnam case, especially in term of Interoperability.

\subsection{Limitations}

However, we still have some limitations:

First, the results of this study can not be generalized to another country because using survey questionnaires in Vietnam.

Second, the profile of responders to the survey is mainly in network administration experts who have experience with Public Management Information System, so did not cover another areas in IT sector.

\section{Conclusion and Future work}

In this paper, we made a survey on adoption promoting interoperability within the public sector and identify the main factors of Interoperability for public management information system interoperability. Due to the necessity for public sector modernization, the ability challenge is turning into bit by bit additional necessary. As each technical and non-technical factors are necessary towards winning implementation of EGovernment systems interoperability; additional holistic framework should be introduced. This paper has detected the wants and key factors for implementing ability. The results of this paper may be used for coming up with a additional holistic e-Government ability framework within the future. 


\section{References}

1 Alavi, M., and Carlson, P. (1992) "A Review of MIS Research and Disciplinary Development," Journal of Management Information Systems, 8:4, pp. 45-62.

2 Alter, S. (2002) Information Systems: Foundations of E-Business, Prentice-Hall, Upper Saddle River, NJ.

3 Ally Lee, Yair Levy, (2014) "The effect of information quality on trust in e-government systems 'transformation", Transforming Government: People, Process and Policy, Vol. 8 Issue: 1, pp.76-100, https://doi.org/10.1108/TG-10-2012-0011

4 Al-Rahbi, Y., Al-Harrasi, S., \& Al-Wahaibi, S. (2012). Technical factors affecting the adoption of egovernment.

5 Barry Bozeman and Stuart Bretschneider (1986)

Public Management Information Systems:

Theory and Prescription

6 Bakos, J. Y., and Brynjofsson, E. (1993) "Information Technology, Incentives, and the Optimal Number of Suppliers," Journal of Management Information Systems, 10:2, pp. 37-53.

7 Benbasat, I., Goldstein, D., and Mead, M. (1987) "The Case Research Strategy in Studies of Information Systems," MIS Quarterly, 11:3, pp. 369-386.

$8 \quad$ Colesca, S. E., \& Liliana, D. (2009). E-government Adoption in Romania. International Journal of Human and Social Sciences, 4(14), 1040-1044.

9 Colesca, S. E., \& Dobrica, L. (2008). Adoption and use of e-government services: The case of Romania. Journal of applied research and technology, 6(3), 204-217.

10 Gottschalk, P., \& Solli-Sæther, H. (2009). Stages of e-government interoperability. In E-Government Interoperability and Information Resource integration: Frameworks for Aligned Development (pp. 108-123). IGI Global.

11 Tripathi, R. P., Gupta, M. P., \& Bhattacharya, J. (2011). Identifying factors of integration for an interoperable government portal: a study in Indian context. International Journal of Electronic Government Research (IJEGR), 7(1), 6488.

12 Sulehat, N. A., \& Taib, C. A. (2016). e-Government Information Systems Interoperability in developing countries: The case of Jordan. Journal of Business and Social Review in Emerging Economies, 2(1), 39-49.

13 Sulehat, N., Taib, C. A., \& Ishak, K. A. (2017). The Moderating Effect of IT Knowledge on the relationship between Organizational Factors and Information Systems... Australian Journal of Basic and Applied Sciences, 11(10), 118-127.
14 Saekow, A., \& Boonmee, C. (2010). A Practical Method of Reducing the Gaps in e-Government Interoperability Implementation: Case of Patient Referral Information Exchange. AISS, 2(2), 93-106.

15 Othman, M. H., \& Razali, R. (2017). Electronic Government Systems Interoperability Model. Journal of Telecommunication, Electronic and Computer Engineering (JTEC), 9(3-4), 1-9.

16 Othman, M. H. B., \& Razali, R. (2013, November). Key contributing factors towards successful Electronic Government systems interoperability. In Research and Innovation in Information Systems (ICRIIS), 2013 International Conference on (pp. 302-307). IEEE.

17 Al-Rahbi, Y., Al-Harrasi, S., \& Al-Wahaibi, S. (2012). Technical factors affecting the adoption of egovernment.

18 van der Veer, H., \& Wiles, A. (2008). Achieving technical interoperability. European telecommunications standards institute.

19 Yan, Z., Sun, B., \& Wang, T. (2009, November). A study on information sharing of e-government. In Grey Systems and Intelligent Services, 2009. GSIS 2009. IEEE International Conference on (pp. 1331-1335). IEEE.

20 Davis, F.D., Bagozzi, R. P. Warshaw, P. R. (1989). User acceptance of computer technology: a comparison of two theoretical models. Management Science, 35 (8) 982-1003.

21 Chen, S. C., Li, S. H., Li, C. Y. (2011). Recent related research in technology acceptance model: A literature review. Australian Journal of Business and Management Research, 1 (9) 124-127.

22 Andrew Vaz, 2014, Expanding the Role of Public Management: From Citizen Participation to Open Government, PA Times online

23 Bensauo, M., and Venkatraman, N. (1996) "Interorganizational Relationships and Information Technology: A Conceptual Synthesis and a Research Framework," European Journal of Information Systems, 5, pp. 84-91.

24 Bingham, R.D. (1976) The Adoption of Innovation by Local Government, Lexington Books, D.C. Heath and Company, Lexington.

25 Brudney, J.L., and Selden, S.C. (1995) "The Adoption of Innovation by Smaller Local Governments: the Case of Computer Technology," American Review of Public Administration, 25:1, pp. 71-85.

26 Benoît Otjacques, Patrik Hitzelberger \& Fernand Feltz (2007) Interoperability of E-Government Information Systems: Issues of Identification and Data Sharing, Journal of Management Information Systems, 23:4, 29-51

27 Chau, P.Y.K., and Jim, C.C.F. (2002) "Adoption of Electronic Data Interchange in Small and Medium-Sized 
Enterprises," Journal of Global Information Management, 10:4, pp. 61-85.

28 Dawes, S.S., Pardo, T.A., Green, D.E., McInerney, C.R., Connelly, D.R., and DiCaterino, A. (1997a) "Tying a Sensible Knot: A Practical Guide to StateLocal Information Systems," Center for Technology in Government, University at Albany/SUNNY, available at http://www.ctg.albany.edu/resources/pdfrpwp/iis1.pdf, accessed on 09/18/02.

29 Dawes, S.S., Pardo, T.A., Connelly, D.R., Green, D.E., and McInerney, C.R., (1997b) "Partners in State-Local Information Systems: Lessons from the Field," Center for Technology in Government, University at Albany/SUNNY, available

http://www.ctg.albany.edu/resources/pdfrpwp/iisfnlrp.pdf, accessed on 09/18/02

30 A. Bandura, Social Foundations of Thought and Action: A Social Cognitive Theory (Prentice-Hall; NJ, 1986).

31 de Ven, A.H. (1976) "On the Nature, Formation and Maintenance of Relationships among Organizations," Academy of Management Review, 1:4, pp. 24-36.

32 A. Cabrera, W. C. Collins and J. F. Salgado, 'Determinants of Individual Engagement in Knowledge Sharing', International Journal of Human Resource Management, Vol. 17, no. 2, 2006, pp. 245-64.

33 Hoang, Trung \& Tran, Kim Hieu, 2015: “AN APPROACH TOWARDS THE INTEGRATION OF BUS INFORMATION SYSTEMS IN VIETNAM"

34 ODNI, 'Intelligence Community Directive Number 301: National Open Source Enterprise', Office of the Director of National Intelligence (ed.) (Office of the Director of National Intelligence; Washington DC, 2006).

35 Jarvenpaa, S.L., and Staples D.S. (2000) "The Use of Collaborative Electronic Media for Information Sharing: An exploratory Study of Determinants," Journal of Strategic Information Systems, 9, pp. 129-154.

36 Attorney-General's Department, 'Information security management guidelines: Australian Government security classification system', Attorney-General's Department (ed.) (Australian Government; Canberra, ACT, 2011).

37 Richard A. Best and Alfred Cumming, 'Open Source Intelligence (OSINT): Issues for Congress', Congressional Research Service (ed.) (Congressional Research Service; Washington DC, 2007), p. 24.

38 Robert Cornall and Rufus Black, 'Independent Review of the Intelligence Community Report 2011', Department of the Prime Minister and Cabinet (ed.) (Australian Government; Canberra, ACT, 2011).

39 Philip Flood, 'Report of the inquiry into Australian Intelligence Agencies', Department of the Prime Minister and Cabinet (ed.) (Australian Government; Canberra, ACT, 2004).
40 Kraemer, K. L., \& Perry, J. L. (1979). The federal push to bring computer applications to local governments. Public administration review, 260-270.

41 Karahannas, M.V., and Jones, M. (1999) "Interorganizational Systems and Trust in Strategic Alliances" in the Proceedings of the Twentieth International Conference on Information Systems, Charlotte, North Carolina, pp. 346357.

42 Rachel Martin, 'CIA Tracks Public Information for the Private Eye', In: National Public Radio. 2012).

43 David R. Lankes, 'Credibility on the Internet: Shifting from Authority to Reliability', Journal of Documentation, Vol. 64, no. 5, 2008, pp. 667-86.

44 Sonja Spiranec and Mihaela Banek Zorica, 'Information Literacy 2.0: Hype or Discourse Refinement?', Journal of Documentation, Vol. 66, no. 1, 2010, pp. 140-53.

45 Sharon Markless and David Streatfield, 'Three decades of information literacy: redefining the parameters', In: Change and Challenge: Information Literacy for the 21st Century. Susie Andretta (ed.) (Auslib Press; Adelaide, SA, 2007).

46 Landsbergen Jr, D., \& Wolken Jr, G. (2001). Realizing the promise: Government information systems and the fourth generation of information technology. Public administration review, 61(2), 206-220.

47 Marc Novakouski, 2012: "Interoperability in the eGovernment Context" European Communities 2008, p.34.

48 Newcomer, K. E., \& Caudle, S. L. (1991). Evaluating public sector information systems: More than meets the eye. Public Administration Review, 377-384.

49 Norris, D. F., \& Moon, M. J. (2005). Advancing egovernment at the grassroots: Tortoise or hare? Public administration review, 65(1), 64-75.

50 Benoît Otjacques , Patrik Hitzelberger \& Fernand Feltz (2007) Interoperability of E-Government Information Systems: Issues of Identification and Data Sharing, Journal of Management Information Systems, 23:4, 29-51

51 Lukas BA, Hult GTM, Ferrell OC. A theoretical perspective of the antecedents and consequences of organizational learning in marketing channels. J Bus Res 1996;36(3):233 - 44.

52 Premkumar, G., \& Ramamurthy, K. (1995). The role of interorganizational and organizational factors on the decision mode for adoption of interorganizational systems. Decision sciences, 26(3), 303-336.

53 Pudjianto, B., Jo, H., Ciganek, P.A. \& Rho, J.J., 2011. Determinants of E-government assimilation in Indonesia: An empirical investigation using TOE framework. Asia Pacific Journal of Information Systems, 21(1).

54 Sinkula JM. Market information processing and organizational learning. J Mark 1994;58:35 - 45. 


\section{Appendix. Questionnaires}

Direction:

The following describe statements about the factors of public organization's e-Government Information System Interoperability. Please indicate the extent to which you agree or disagree with the statements based on the scale provided.

\begin{tabular}{|c|c|c|c|c|c|c|}
\hline $\begin{array}{l}\text { Strongly } \\
\text { disagree }\end{array}$ & Disagree & $\begin{array}{l}\text { Slightly } \\
\text { disagree }\end{array}$ & \multicolumn{2}{|c|}{$\begin{array}{l}\text { Slightly } \\
\text { agree }\end{array}$} & Agree & $\begin{array}{l}\text { Strongly } \\
\text { Agree }\end{array}$ \\
\hline 1 & 2 & 3 & \multicolumn{2}{|c|}{4} & 5 & 6 \\
\hline \multicolumn{4}{|c|}{ Statements } & \multicolumn{3}{|c|}{ Level of Agreement } \\
\hline \multicolumn{7}{|c|}{$\begin{array}{l}\text { Risk management. It is defined as formal continuous } \\
\text { process to avoid the failure of EGISI }\end{array}$} \\
\hline \multicolumn{4}{|c|}{$\begin{array}{l}\text { RM1. Visible committee } \\
\text { (Your organization has a } \\
\text { visible risk management } \\
\text { committee for EGISI.) }\end{array}$} & & & \\
\hline \multicolumn{4}{|c|}{$\begin{array}{l}\text { RM2. Fulladequate system } \\
\text { (Your organization has an } \\
\text { fulladequate information } \\
\text { system to register, monitor } \\
\text { and report risks for } \\
\text { EGISI.) }\end{array}$} & & & \\
\hline \multicolumn{4}{|c|}{$\begin{array}{l}\text { RM3. Frequency of check } \\
\text { (Your organization repeats } \\
\text { the process of risk } \\
\text { assessment regularly) }\end{array}$} & & & \\
\hline \multicolumn{4}{|c|}{$\begin{array}{l}\text { RM4. Frequency of } \\
\text { backup (Your organization } \\
\text { performs backup for the } \\
\text { EGIS in a regular bases is } \\
\text { necessary.) }\end{array}$} & & & \\
\hline \multicolumn{4}{|c|}{$\begin{array}{l}\text { RM5. Quality of backup } \\
\text { (Your organization's } \\
\text { disaster recovery site } \\
\text { works well.) }\end{array}$} & & & \\
\hline \multicolumn{7}{|c|}{ Collaboration and Coordination.. } \\
\hline \multicolumn{4}{|c|}{ 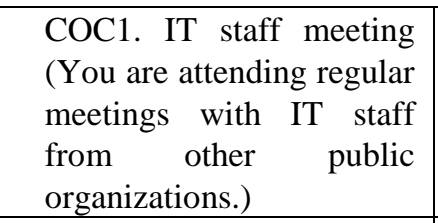 } & & & \\
\hline \multicolumn{4}{|c|}{$\begin{array}{l}\text { COC2. Make agreement } \\
\text { together } \\
\text { organization participate } \\
\text { frequently in formulating }\end{array}$} & & & \\
\hline
\end{tabular}

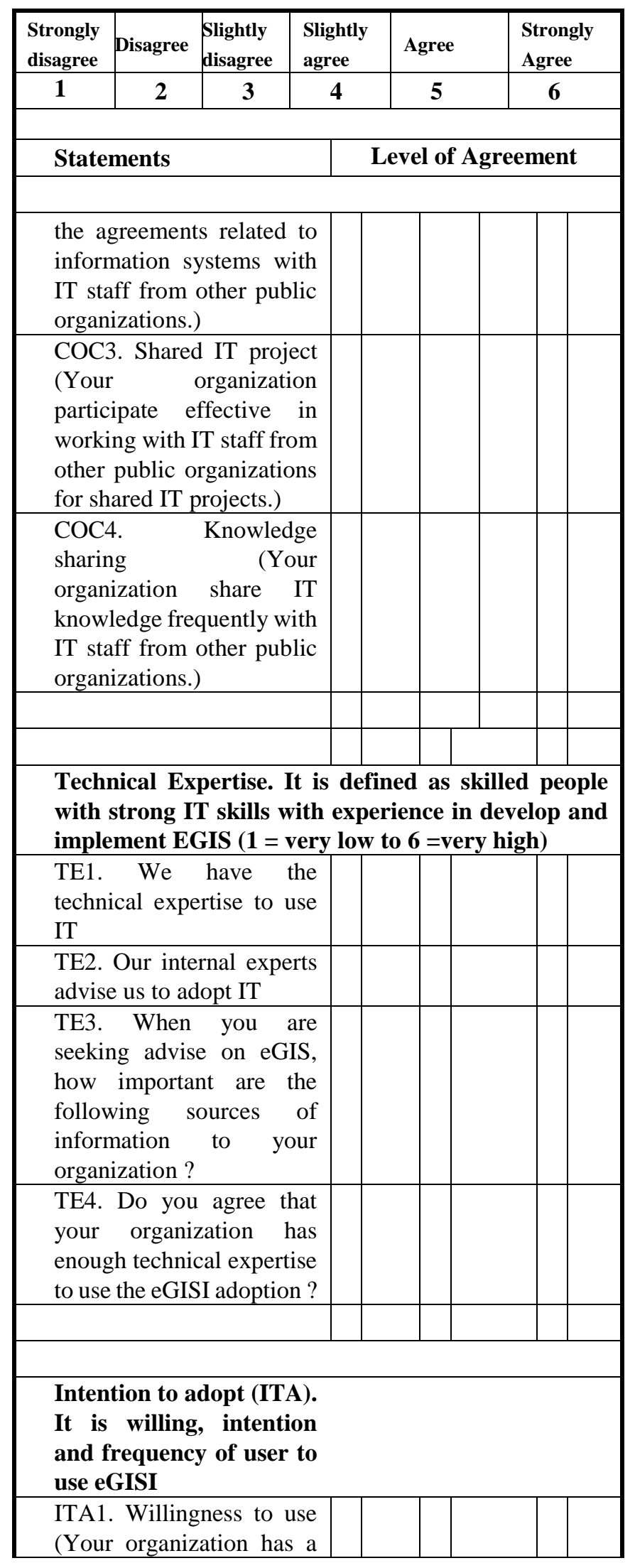




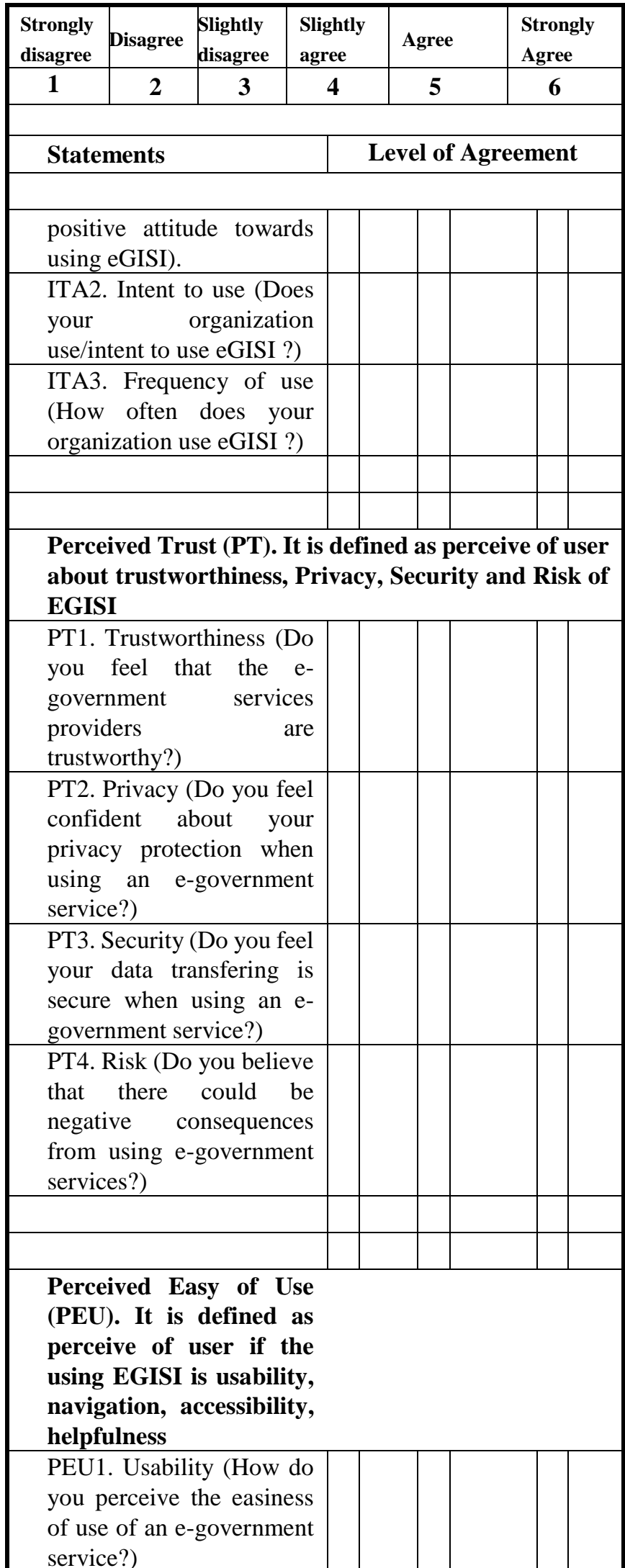

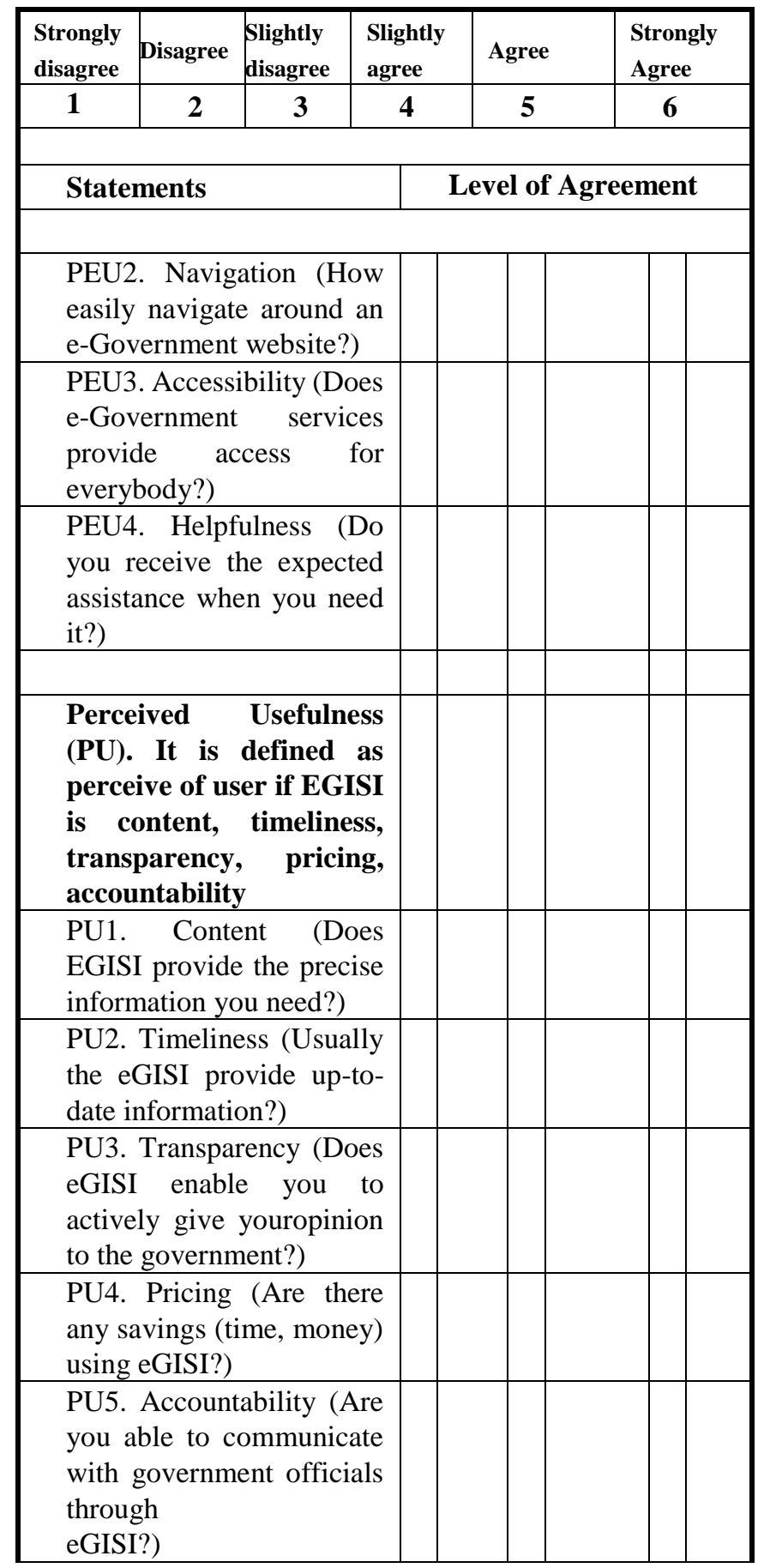

